\title{
A Model Proposal for Solving Problems Encountered in Performance Tasks
}

\section{Melek Gülşah Şahin (D) 1, Nagihan Boztunç Öztürk (D) 2,*}

\author{
${ }^{1}$ Gazi University, Gazi Education Faculty, Department of Measurement and Evaluation in Education, Turkey \\ ${ }^{2}$ Hacettepe University, Lifelong Learning Center, Turkey
}

\section{ARTICLE HISTORY}

Received: 28 March 2018

Revised: 29 May 2018

Accepted: 04 August 2018

\section{KEYWORDS}

Performance tasks,

Measurement and evaluation,

Classroom assessment,

High school education

\begin{abstract}
This study aims to establish a model proposal for solving problems in the use of performance tasks at the high school level. The study which adopted qualitative research method was planned in two stages. First, the problems faced by high school teachers $(n=40)$ using performance tasks were determined, and for the second stage the opinions of academicians ( $n$ $=8$ ) related to the solution of the determined problems were consulted. Three stakeholders were identified in solving the problems identified during the first step of the study; those being the university, the Ministry of National Education (MoNE), and the teachers. Although the perceptions of the teachers' use of performance tasks in general were positive, it was seen that there problems were experienced in their application. Emphasis was placed on the importance of communication between the university, the MoNE and the teachers in order to overcome these problems. For the effective function of performance tasks, points such as diversity in classroom practices, attention to the characteristics of students and environmental conditions, and the use of rubrics were emphasised.
\end{abstract}

\section{INTRODUCTION}

The concept of skill seems to have already taken over the $21^{\text {st }}$ century. In order to be considered ready for the $21^{\text {st }}$ century, humanity has been conducting research, changing educational systems, introducing new job descriptions, and seeking out workers with $21^{\text {st }}$ century skills (critical thinking, problem solving, creativity, innovation, collaboration, etc.). In the global sense, it has passed from a time where knowledge was the first thing that came to mind when success was mentioned, to a time when skills are the primary consideration. The concept of skill is now a global concept, yet the problems of actually training future employees for unspecified occupations remains a generic task for the future.

Skillsets have become the worldwide employment passports of the $21^{\text {st }}$ century. If proper investment is not undertaken in skills, people suffer on the edges of society, technological

CONTACT: Nagihan BOZTUNÇ ÖZTÜRK $₫$ nagihanboztunc@hacettepe.edu.tr $\equiv$ Hacettepe University, Lifelong Learning Center, Ankara, Turkey 
development does not turn into economic advancement, and international competitiveness may not be achieved in a global society built on knowledge. The nature of employment has altered considerably over the past decade, and the demand for ability has been increasing in OECD countries and beyond. Job shifts have been observed from the agricultural lands to the factories and professional workplaces in OECD countries from the 1960s through till recent measures were taken in 2009 (OECD, 2012). Information evaluation and analysis skills, and using these skills practically in the real world, have become of significant importance for students because they are the required specifications for the professions and for the leaders of higher education (O'Sullivan \& Dallas, 2010). The need to have students with these skills has led to the need for educational training programmes to be updated. There is a worldwide common interest to change the educational vision by advocating views that are referred to as 'deeper learning' and ' $21^{\text {st }}$ century skills' (Pellegrino, 2017). Educational researchers have been discussing how $21^{\text {st }}$ century skills such as critical thinking, problem solving, collaborative working, and communication can be taught and how it can be evaluated.

In terms of its evaluation, when $21^{\text {st }}$ century skills are considered, it is emphasised that formative and summative assessments should be planned in order to complement each other (OECD, 2017; P21Skills, 2007). It is important to establish an evaluation balance between high quality standardised tests and effective formative assessment. Formative assessment of $21^{\text {st }}$ century skills in an effective way should carry a number of characteristics. Firstly, it should concentrate on $21^{\text {st }}$ century skills and ideas, then it should make the thinking visible by exposing the conceptual strategy types that a student exploits in their problem solving. In addition, it must be structured in a way that the teachers can determine the background knowledge used by students to solve problems in the real world. It also should be genuine and based on performance; demanding that students apply their $21^{\text {st }}$ century skills. It should derive data that can be used to directly inform teaching practices, and it should have a goal to form capacity for both teachers and students. In addition, it must form part of a comprehensive assessment continuum and display a sense of learning as complex, integrated, and as shown in actual performance (P21Skills, 2007). The performance tasks, which are among the formative assessment tools, are activities aimed at developing and measuring students' high-level cognitive skills, and presenting problem situations that students may encounter in real life (Kutlu, Doğan, \& Karakaya, 2009). Looking at the characteristics of formative assessment of $21^{\text {st }}$ century skills, it is clearly seen that performance tasks should be employed; and McTighe (2016) stated that two or more $21^{\text {st }}$ century skills can be involved in performance tasks.

In Turkey, performance tasks have been implemented in primary school grades 1-5 from the 2005-2006 academic year and implemented gradually in other grades from 2006-2007 (Gelbal $\&$ Kelecioğlu, 2007). Performance tasks were added to high school curricula under an education regulation dated 07.09.2013 (Milli Eğitim Bakanlığı [Ministry of National Education], 2013).

Problems have been encountered over time in the accomplishment of performance task evaluation such as tasks not having the ability to measure high-level skills, the ability to evaluate students in the process, lack of encouragement of using skills such as responsibility and communication skills and so forth. Benefits provided by performance tasks have been replaced by problems such as tasks being performed more by the families of students, that students copy information directly from the Internet, that evaluation takes time, and that students only perceive it as another grade to be achieved. In 2008, the MoNE introduced some 
measures regarding the more effective use of performance tasks in educational processes. However, since these measures did not produce the desired results, the performance tasks were abolished in elementary schools under a regulation change in 2014 (Türk Eğitim Derneği [TED], 2014).

When the academic studies related to performance tasks are examined; it is seen that although the perceptions about performance tasks are generally positive, some problems in classroom practices (insufficiency in lesson hours, parental support, resources, appropriate performance tasks for students' level, overcrowded classrooms, shortage in objective assessment, time taken for evaluation etc.) have been encountered (Ak, 2013; Ar1, 2010; Arslan, 2013; Aydin, Yörek, \& Uğulu, 2015; Bal, 2012; Benli, 2010; Dilekmen \& Aydoğdu, 2015, Göçgen, 2016; Metin, 2013; Palaz, Kılcan, Akbaba, \& Çepni, 2015; Sarı, 2014; Seyhan, 2017; Tanrıverdi, 2012). However, there are also studies to be found in the literature showing that when performance tasks are used effectively, students are positively influenced in terms of their attitudes towards the classroom, creativity, learning, tendency to think critically, their development of collaborative skills, self-esteem, and their problem-solving skills (Aslan Yolcu, 2013; Bayrakçı, 2010; Ekici, 2016; Furat, 2009; Gürel, 2012; Kutlu et al., 2009; Öztürk, 2010; Sözer, 2015).

The problems encountered were seemingly not down to the features of the performance tasks, but mainly due to the assessment tool not being applied correctly (Türk Eğitim Derneği [TED], 2014). The removal from the curricula of the performance tasks, which have an important place in the evaluation of $21^{\text {st }}$ century skills, and the lack of any substitute method creates a deficiency in the Turkish educational system. For this reason, it is important to present solutions for the effective use of performance tasks. When the published literature is examined, it can be seen that the majority of studies have been carried out at the primary education level. Performance tasks have not yet been removed from high school education institutions; this being the case, determining problems related to performance tasks and presenting solution proposals are important in terms of informing the appropriate decision-making units.

The current study aims to present a model proposal to address problems encountered in the implementation of performance tasks at the high school level. For this purpose, answers are sought to the following research questions.

1. What problems do high school teachers encounter with regard to performance tasks?

2. What kind of a model can be proposed to increase the reliability, validity, and usefulness of performance tasks?

\section{METHOD}

A qualitative research methodology has been adopted in this study. The qualitative approach is a method that can reveal the opinions and perspectives of individuals about the subject being investigated, and to reveal sub-factors forming these aspects (Yıldırım \& Şimşek, 2008). The study has been conducted in three stages. In the first stage of the research, high school teachers working in Ankara, Turkey, were asked to identify problems experienced with performance tasks. In the second stage, in line with the teachers' opinions obtained in the first stage, faculty members were requested to propose solutions. In the third stage, a model will be proposed in light of the outcome of the first two stages of the study, and from examining the published literature. 


\subsection{The Participants}

The participant group of the first stage of the research constitutes 40 teachers working in state high schools in Ankara, Turkey. In the study, maximum diversity sampling, one of the purposeful sampling methods was selected. The frequency distribution according to the demographic characteristics of the participant teachers is presented in Table 1.

Table 1. The demographic characteristics of the teachers

\begin{tabular}{|c|c|c|c|c|c|c|c|}
\hline Variables & Category & $\mathrm{f}$ & $\%$ & Variables & Category & $\mathrm{f}$ & $\%$ \\
\hline \multirow{2}{*}{ Gender } & Female & 25 & 62.5 & \multirow{10}{*}{ Major } & Mathematics & 7 & 17.5 \\
\hline & Male & 15 & 37.5 & & Turkish Philology & 6 & 15.0 \\
\hline \multirow{6}{*}{ Age } & $24-30$ & 8 & 20.0 & & English & 4 & 10.0 \\
\hline & $31-35$ & 8 & 20.0 & & Physics & 5 & 12.5 \\
\hline & $36-40$ & 9 & 22.5 & & Chemistry & 4 & 10.0 \\
\hline & $41-45$ & 5 & 12.5 & & Biology & 3 & 7.5 \\
\hline & $46-50$ & 5 & 12.5 & & History & 3 & 7.5 \\
\hline & $51-55$ & 5 & 12.5 & & Philosophy & 2 & 5.0 \\
\hline \multirow{2}{*}{$\begin{array}{l}\text { In-Service Training on } \\
\text { Measurement and } \\
\text { Evaluation }\end{array}$} & Yes & 14 & 35.0 & & Geography & 2 & 5.0 \\
\hline & No & 26 & 65.0 & & Others* & 4 & 10.0 \\
\hline \multirow{5}{*}{$\begin{array}{l}\text { Professional Seniority } \\
\text { (year) }\end{array}$} & $0-5$ & 11 & 27.5 & \multirow{5}{*}{$\begin{array}{l}\text { Average } \\
\text { Number of } \\
\text { Students }\end{array}$} & 20 and below & 2 & 5.0 \\
\hline & $6-10$ & 4 & 10.0 & & $21-30$ & 18 & 45.0 \\
\hline & $11-15$ & 6 & 15.0 & & \multirow[t]{3}{*}{31 and over } & \multirow[t]{3}{*}{20} & \multirow[t]{3}{*}{50.0} \\
\hline & $16-20$ & 6 & 15.0 & & & & \\
\hline & 21 and over & 12 & 30.0 & & & & \\
\hline
\end{tabular}

*Other majors are music, physical education and French language

Table 1 shows that $25(62.5 \%)$ of the teachers are female and $15(37.5 \%)$ are male. According to the age variable, nine $(22.5 \%)$ of the teachers are in the 36-40 age bracket. As to their education, $52.5 \%$ of the teachers graduated from an education faculty. When the distribution according to the branch variable is examined, seven (18\%) of the teachers are from the mathematics department. In terms of their seniority, 11 of the teachers $(27.5 \%)$ have $0-5$ years' experience. The distribution of the average number of students in the teachers' classes shows an average of 31-40 students in the classes of the $20(50 \%)$ of the teachers. Also, $26(65 \%)$ of the teachers stated that they did not receive any in-service teacher training about measurement and evaluation.

In the second stage of the research, eight faculty members from an educational faculty at a university were interviewed. The reason for the selection of experts from four basic areas in educational sciences was that when the limitations and the literature (Ar1, 2010; Aydın et al., 2015; Benli, 2010; Çiftçi, 2010; Metin, 2013; Sarı, 2014) were examined, it was thought that interdisciplinary solution proposals would be more appropriate and meaningful. Before being selected for interview, it was checked that each of the experts had studied the subject, that they followed up-to-date information, and that their solution proposals would be about specified limitations from their own fields. Information about the coding of the experts in the study is presented in Table 2.

Table 2. The information of the coding about the experts

\begin{tabular}{lll}
\hline Code & Department & Professional Seniority (year) \\
\hline E1-E2-E3 & Educational Measurement and Evaluation & $16-17-10$ \\
E4-E5 & Curriculum and Instruction & $18-8$ \\
E6-E7 & Educational Administration & $10-12$ \\
E8 & Guidance and Psychological Counseling & 12 \\
\hline
\end{tabular}




\subsection{Data Collection and Analysis}

The research was conducted in three stages. In the first stage of the research, the Teacher Opinion Form developed by the researchers was used to collect the data. Two measurement and evaluation experts reviewed the form, and it was finalised after the necessary corrections were applied. The form consists of two parts. Demographic information was sought in the first part, whilst in the second part, open-ended questions about opinions as to the problems experienced with regard to performance tasks were asked. The form was personally handed to the participant teachers by the researchers and then the questionnaire administered. Researchers collected the forms by hand, after waiting for the teachers to complete the form. Content analysis was applied to the data obtained from the form. Content analysis makes it possible to examine verbal, written and other materials objectively and systematically (Tavşancıl \& Aslan, 2001). According to Y1ldırım and Şimşek (2008), the main goal of content analysis is to reach the concepts and associations that can explain and thereby describe the data. For this purpose, first of all, conceptualisation of the data and then necessary logical arrangements must be made to create themes. The NVivo analysis software program was used in the analysis of the data.

In the first stage of the study the researchers transferred the data to an electronic media in order to establish the validity of the study. The data were examined and discussed by the researchers and then categorised. The researchers consulted with another expert in the field of measurement and evaluation in case of any problems in the data coding and naming, thus a consensus was achieved. In addition, the data based on the formation of each category are given clearly in the Findings section. After the categories were identified, two measurement and evaluation experts' opinions were asked about the convenience of the categories. Then the feedback regarding the naming of the categories and data classification were evaluated one by one by the researchers working together, and their final versions were decided. Moreover, in order to assure the validity of the study, direct citation (Yıldırım \& Şimşek, 2008) has been included, with the researchers' own cues included as quotations.

In the second stage of the study, the aim was to take the views of academic members from a university faculty about the problems determined based on the opinions of the teachers and to elicit their suggestions for practical solutions to the reported problems. For this purpose, a semistructured Expert Interview Form was created by the researchers. The expert interview form consists of two parts. Questions relating to demographic information about the experts formed the first part of the form. In the second part, codes obtained from the first stage of the study were used in accordance with field expert guidance to form questions relating to solution proposals to the problems reported, and to their solutions' limitations. At this stage, researchers should note that the study should be considered as being related to performance tasks. Prior to receiving expert opinion, the expert interview form was emailed to the experts and they were informed about the purpose, scope and the content of the study. The opinions of the experts were taken in face-to-face meetings by the researchers that lasted for 25-30 minutes. The experts' opinions were first transcribed then returned for their approval; after which, they were included in the study. Content analysis was also used in the analysis of the data obtained at this stage. The same data analytical path of the first stage was also followed for this second stage.

In the third phase of the study, a model was proposed by the researchers based on the previous two stages and from the literature. Opinions of two measurement and evaluation experts were gathered in order to assess the clarity of the proposed model and its compatibility with the information obtained from the other two stages. The model was finalised to include any proposed amendments.

Yildirım (2010) mentioned a number of measures that could be applied by the researchers so as to improve the quality of the qualitative research. For this purpose, detailed explanations and 
descriptions are made and the research carried out within certain limits. In addition, co-audits were carried out both in the creation of the themes and coding; and also, when considered necessary, external expert opinion was sought. Additionally, the data collection and analysis process is clearly presented in the study. Direct quotations of the teachers and from the expert opinions are included as direct evidence of the reliability of the data obtained in the study.

\section{FINDINGS}

In this part of the study, findings related to each sub-problem were presented.

\subsection{First Sub-Problem}

In this sub-problem, the teachers' opinions about the problems experienced with performance tasks are stated. A total of seven categories were derived from the teachers' views, which are; Preparation-Evaluation Difficulty, Facility Limitation, Subject Limitation, Students' Perspective, Students' Access to Effortless Knowledge (Copying), Time Limitation, and Being Compulsory. Examples and interpretations for each category are presented as follows.

a. Preparation-Evaluation Difficulty ( $f=8$ ): Teachers stated that there was difficulty in preparing the performance tasks appropriately for the age of the students and purpose of the task. They also mentioned that the evaluation was time consuming and difficult, and touched upon its limitations. For example, while T5 referred to tasks not prepared according to student age by saying 'It was unable to be prepared properly for the age of the students'; T27 stated that it could not be prepared according to its purpose by saying, 'It is difficult to prepare an appropriate performance task for its purpose'. Besides, T26 stated that 'evaluating is subjective', whilst T26 referred to the difficulty of evaluation as 'not seeing the point that the student does not understand'.

b. Facility Limitations ( $f=5$ ): As for the limitations of performance tasks, the teachers stated that classes were overcrowded, that there were no studying opportunities outside of the home and library, and that some students did not have the same opportunities. For example, T19 mentioned class overcrowdedness as, 'individual works cannot be accomplished, only group work can be done because of the overcrowded classes', and T40 referred to the facilities that some families provided as being limited by saying, 'some cannot have the same opportunities'.

c. Subject Limitation ( $f=5$ ): Teachers mentioned limited subject options for some performance tasks. For example, T13 stated that, 'We are obliged to give homework on certain topics'. T25 expressed that 'they are narrow-scoped' and T34 stated, 'It can be a problem when only limited to one subject'.

d. Students' Perspectives ( $f=6$ ): Teachers mentioned the limitations of performance tasks due to their students' perspectives, noting that students were reluctant to prepare performance tasks, that they did not take them seriously, that they just saw it as another grade and that they did not like preparing them. For example, T28 stated that students might have problems due to their grade-oriented thinking, expressing that 'students may not take it seriously when its grade weight is low'. While T21 mentioned that the creativity of students could be thwarted since it was regarded as just a grade point, indicating 'and the student sees it only as a grade raiser', and T39 emphasised that the students did not want to spend time with such work, saying 'it is perceived as a waste of time for the student'.

e. Students' Access to the Effortless Knowledge (Copying) ( $\mathrm{f}=4)$ : Teachers indicated that pupils received parental help in preparing their performance tasks and copied from the Internet. T9 referred to the limitation of receiving family members' help, expressing that 'It is predominantly prepared by the parents when they are prepared at home', whilst T16 mentioned 
that students made no effort, saying 'Students have to copy and they copy easily from the Internet due to the fact that similar tasks have been performed before'.

f. Time Limitation ( $f=9$ ): Teachers stated that limited classroom hours and performance task preparation time as a limitation. For example, T3 mentioned the time limit and that the tasks were not ideally prepared, stating 'There is a time limit effect as performance tasks cannot be prepared as desired'. While T8 pointed out imprecise preparation of homework with 'Cursory homework can occur when the time is limited for the student', T18 stated that students are unable to reveal their creativity, saying 'The limitations in terms of subject and time can prevent students' creativity and contribution'.

g. Being Compulsory ( $f=3$ ): Teachers stated that making performance tasks compulsory for each course was a limitation. They pointed out that the students' motivation decreased when it became compulsory. T25 said 'It is not expected that the student is willing, it can be considered as an obligation, not voluntary', while T21 expressed 'the efficiency decreases due to the fact that it becomes compulsory for all the branch teachers'.

\subsection{Second Sub-Problem}

In this second sub-problem, a model proposal was made based on the findings of the first subproblem and on expert opinion. The conceptual figure of the proposed model is presented in Figure 1.

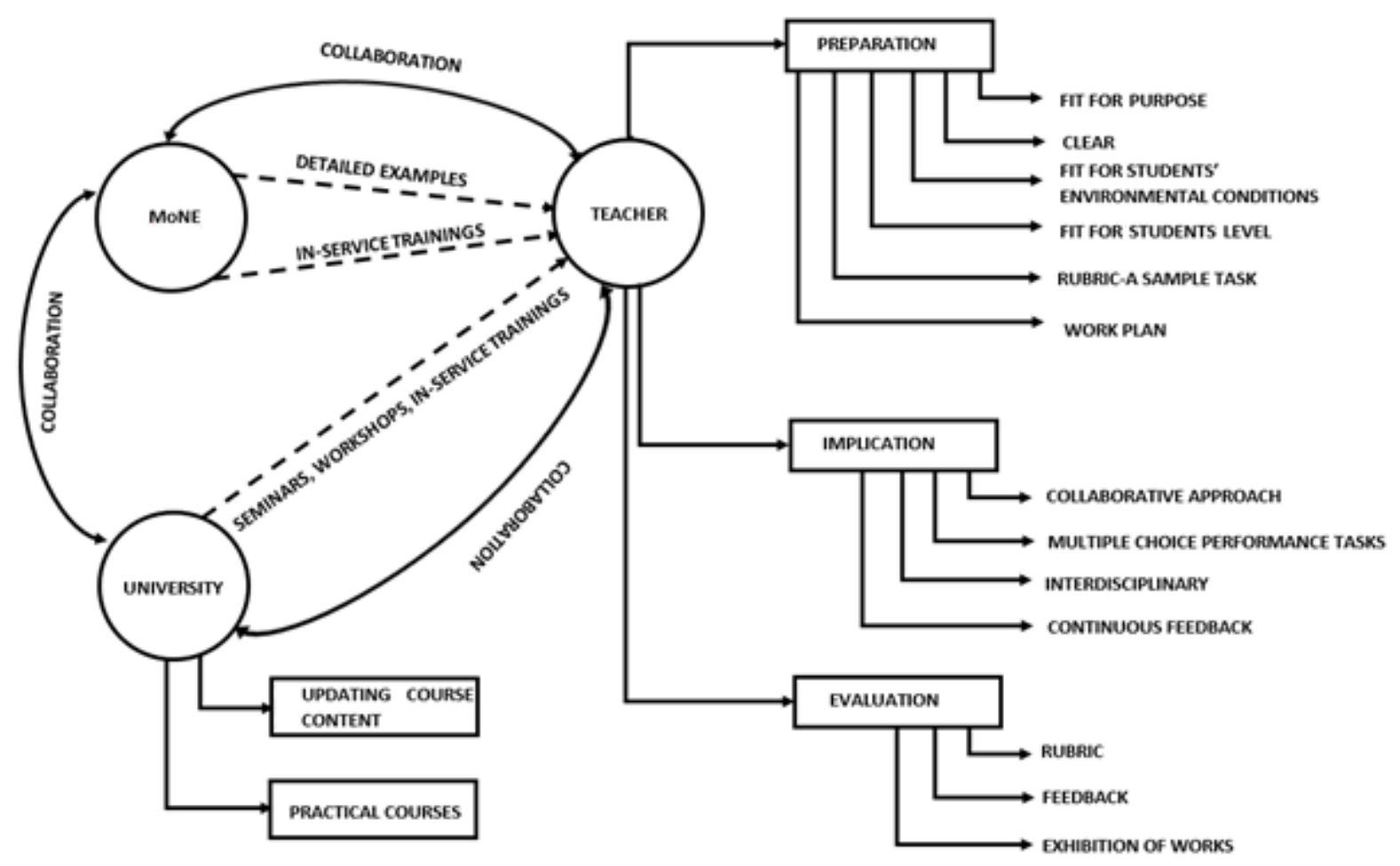

Figure 1. Conceptual figure of proposed model

As can be seen in Figure 1, the University, the MoNE, and Teachers are the three stakeholders involved in the model presented to overcome the limitations of performance tasks and projects. The relations between the relevant stakeholders, their duties, and the expert opinions used to form the model are detailed in the following subsections. 


\subsubsection{University}

In the content of the university stakeholder, there are proposals such as keeping the existing values up-to-date, proposing practical courses for the curriculum, cooperation with both the MoNE and teachers, and seminars, workshops and in-service training for teachers. The explanations for each proposal are presented as follows.

a) Including practical courses in curriculum and updating course content: In university faculties of education, it may be proposed that prospective teachers are offered lessons which require knowledge and skills expected of them in the future, and in which they have the opportunity to practice measurement and evaluation methods. In addition, teachers may be asked to apply measurement tools which they will practice as of the beginning of their teaching profession. Sample views are presented as follows.

E1: It seems that the prospective teachers have little time for the performance evaluation and rubrics in the scope of the measurement and evaluation course they have taken during their education. .... In this case, it would be better to devote more time to these issues and to carry out practice-directed studies. So the course has to be directed towards the field. For this, a course under the name of Measurement and Evaluation Practices can also be offered.

E2: Although their performance tasks are very good, because of the teacher candidates' lack of knowledge and skills on teaching methods, they cannot be implemented. In addition, as an elective course at the undergraduate level, it is necessary to offer a "Measurement and Evaluation Practices in Schools" course.

E4: The limited availability of opportunities that teachers mentioned is a limitation that prospective teachers can overcome with the Instructional Material Design lessons they have taken during their undergraduate education....Even, if all the universities and schools worked in cooperation, it would be possible to train teacher candidates better by updating the content of relevant course to meet the field needs.

E6: In teacher training programmes, in cooperation with the HEC (Higher Education Council), it could be possible for the topics of performance and project tasks to take on an increased role in various courses of the curriculum.

b) Collaboration with the MoNE: Universities may be recommended to cooperate with the MoNE particularly about the determination of needs, structuring in-service teacher training programmes and the preparation of programme contents. Sample views are presented as follows.

E3: It is important that universities work in coordination with the MoNE, especially in transferring information about the measurement of high-level skills and the resolution of the problems encountered.

E4: If universities and schools work in cooperation, the relevant course content can be updated to meet the needs of the field in order that teacher candidates can be better educated.

E6: Universities should cooperate with the MoNE in the presentation of solution proposals, and especially in determining teachers' needs. Particularly in the preparation of the programme contents, the views of relevant academic faculty members are important.

c) Providing Seminars, Workshops and In-service Trainings for Teachers: It may be suggested for universities that faculty members who work in related fields to arrange seminars, workshops and in-service teacher training to address the practical knowledge deficiency of teachers and to resolve the problems they encounter. Some sample views are presented as follows.

E5: Teachers can be informed with different and correct examples with in-service teacher training programmes which can be offered by academic faculty members to teachers especially to determine and measure high-level mental skills. 
E6: Conferences, seminars, and workshops can be organised in cooperation with universities and schools to resolve the current problems of teachers in preparing and evaluating projects and performance tasks.

\subsubsection{The Ministry of National Education}

a) In-service Teacher Training Program: The Ministry of National Education could organise and enhance programmes related to the regulation of in-service teacher training. The following opinions were noted in connection with this.

E2: Teachers will benefit more if the materials provided to them during training are visual materials. The materials have to be interesting, visual and fit for the real purpose.

E4: I think that teachers should be offered in-service teacher training if they feel inadequate about assessing performance tasks and projects; and that this training should definitely be practical in nature. For example, on the difficulty of evaluation, teachers could be trained on how to evaluate the relevant measurement tools through in-service training.

E6: Firstly, the Ministry of National Education In-service Teacher Training department could increase in-service teacher training on performance tasks and the preparation and evaluation of projects.

E8: They could also provide counselling services to teachers on the effective communication with their students. By this means, they could raise awareness in providing constructive feedback, rewarding students, and not judging or blaming students when they fail.

b) Presenting detailed examples to the teachers: Teachers may be provided examples in the curriculum or separately in the material pool. Thus, the teachers will be informed about the appropriate measurement tools in the evaluation of high-level skills and about the measurement tools appropriate for the students' level. Example views are presented as follows.

E2: The teachers need to know what the performance task is. If there is a lack of basic information; even in the virtual environment, detailed informative examples about the performance task types could be shared with the teachers.

E5: For students of different levels, detailed information could be included in the teacher's manual, and grading keys can be provided with the sample performance tasks and projects.

E6: The MoNE Regulation of High School Education Institutions may include more descriptive information and examples of project and performance tasks, i.e. the stages of preparation and evaluation may be further elaborated.

\subsubsection{Teachers}

Suggestions were provided for teachers under the titles of Preparation, Implementation and Evaluation, which are detailed as follows.

\subsubsection{Preparation}

a) It should be clear: It may be suggested that teachers determine the purpose clearly in the preparation phase of both measurement tools. The purpose should not be directed to grading, but rather, if the intended purpose is to develop high-level mental skills of the students, the students will only demand help from outside when they are in difficulty. Sample views on this are presented as follows.

E1: If we look at the stages where the relevant measurement tools are implemented, the first thing that comes to mind is the need to provide clear goals. For this, students need to understand exactly what is expected of them and to direct their work accordingly. Besides, unnecessary performance tasks that are not within the scope of the determined purposes should be avoided....For both measurement instruments, the guidelines should be given as clear as possible. The rubrics must also be shared with the students in advance. 
E4: Families' and teachers' opinions also affect students seeing these tasks as simply grades. By emphasising their importance in real life, telling the students that these tasks are not just grades, but explaining what good it could do, would better motivate the students.

E7: Since the goal is to improve the sense of responsibility in students and to make the student produce better, the current limited external support could serve much more for this purpose. When the responsibility is assigned to someone else (e.g., mother, father, sibling, friend), it is unlikely that the target behaviour will develop in the student. In order to avoid this, teachers should openly negotiate the situation with all relevant parties, notably the students. And they also should clearly state the expectations as a benefit for the students.

E8: It is very important for students' identity development that they feel the sentiment "I did this with my own work and I presented a solution to this problem". The students in this developmental period should not be distracted by what they think is a waste of time. It has to be more realistic.

b) Fit for purpose and at students' level: The students will be responsible for learning if it is suitable for the purpose of the task and aimed at their level. In addition, tasks that are not fit for purpose or at the students' level should be avoided, as it may demotivate them. Example opinions on this are as follows.

E1: Except for the intended purpose, unnecessary performance tasks should be avoided.

E2: Teachers must first be given a limited performance task during their practical training. Skills acquisition for the relevant tasks should be provided; then an extended performance task must be provided. Tasks should be arranged proportionally and according to the class flow.

E3: Tasks that are not in accordance with the level of the students' readiness will cause behaviours of seeking external help.

E4: It is very important to know the level of students' readiness when performance tasks are given. The fact that a performance task is appropriate for the class level does not mean that it can be done. If the students' readiness level is not suited to the task, firstly the deficiencies should be addressed and then the performance task should be started. In this way, students can tackle the performance task on their own and with less support of their families.

E7: It is necessary to take into account the students' cognitive and emotional characteristics, the appropriateness of the students' readiness and the availability of opportunities.

E8: While assigning performance tasks, importance should be given to the students' developmental characteristics. In addition to the cognitive and emotional characteristics, it is necessary to take into account the turbulence in the psychology of this group of adolescents.

c) Task strength should be emphasized: Teachers should emphasise clearly what high-level skills the students are expected to develop. This approach motivated the students. Some of their sample views are as follows.

E5: With interdisciplinary tasks assigned to students, the skills of the students will develop through this task which can remove subject options limitation from this study. At the same time, the motivation of learners who know their skills in other subjects will be strengthened, will also increase....It should be emphasised that task are directed towards the developmental areas of the students in this process.

E8: The tasks that the students will perform should be part of a pragmatic structure and whatever is to be done should contribute to the students getting into university. If a student devotes her time to study, the task needs to be structured so that she can realise emotional satisfaction, and so she can see concrete contributions to her life in order to plan her life. The performance tasks and projects can make students feel useful in terms of their own identity development. Teachers need to emphasise the unique strengths of each work.

d) The rubric and a sample task should be presented: It is advisable to present the rubric and a sample task report to the students. It is important in terms of time management and motivation. Example opinions are below.

E1: .... The rubrics must also be shared with the students beforehand. In this way, the students will understand the process better and will not need the support of others by easily guiding themselves in 
their works ...... With the desired works, sample works can be shared with the students. It can also be a guide for students.

E3: ... the student must be informed about on what criteria they will be assessed. This is important for the students in structuring their tasks. They try to strengthen the criteria that they will be evaluated with rather than dealing with the questions of whether this or that will be assessed... Previously prepared tasks can be presented to the students, which will be a roadmap to them ...

e) A work plan should be established: Establishing a work plan is crucial in terms of time management, especially where time is limited. It will support more effective work. Sample views on this were as follows.

E1: Especially about the project, in order to make time management more efficient, the teacher should create a schedule at the beginning of the task and pay attention to the student's compliance with the schedule.

E3: A work plan must be established and this plan must be adhered to because it is important for student guidance.

E7: The main things that should be considered in the performance tasks and the projects are specifying when the task will be fulfilled and whose support should be sought in the fulfilment of the task.

f) It should conform to the students' environmental conditions: If the task expected from the students are given in accordance with the environment and facilities of the students, they will prepare it themselves and they will not need any external material support. Example views are as follows.

E2: I do not think there would be a material-based problem in the performance task; but if this kind of problem occurs, I think the main problem would be that the performance task is not suited to the environment.

E5: It is important to remember that creativity is important, as everyone has to prepare tasks with their own means. Tasks using the material facilities do not make much sense; on the contrary, it should also be emphasised that it is more important for a student to prepare his work by using his creativity within the bounds of possibility... and that the expected outputs of the performance and project tasks should never be materially enforced, and it should be expected that each student should use easily accessible objects.

\subsubsection{Implication}

a) Collaborative Approach: By adopting a collaborative approach, the students' motivation will increase and their senses of responsibility develop. Sample views on this are presented as follows.

E4: Performance tasks can not only be done individually, but also as group work. By this means, the students can learn to collaborate as well as self-evaluate. Along with cognitive development, social skills can also be developed.

E7: It will be useful to follow a process or approach that will transform learning not into competition, but into cooperation. For this, performance tasks or projects can be given as group-works, and not as individual works.

E8: Students at the high school level are unfortunately not at a stage whereby they just sit and do their homework. They have difficulties in puberty; at this stage, friends are more important than family, teachers, managers. That's why it can be suggested that the assigned tasks should be realistic and that group work should be emphasised.

b) Continuous feedback should be given: Teachers' continuous feedback is important in terms of effective teacher guidance. Thus, if there is a problem in a student's work, it will be immediately noticed and the necessary corrective action can be taken. Sample views regarding this are as follows. 
E1: The evaluation of the product should not be left to the end, and intermediate checks are required. In short, piecemeal evaluation of the project will provide a more effective time management.

E4: The people who know the students best are their teachers. They know what the students are able to do or what not to do. By deciding whether the task will be a group work or an individual work, they can make very good things happen. If students effortlessly find ready information (so they can copy it) and this is realised by the teacher and tolerated, then undesirable behaviours will continue to develop in the student. For this reason, teachers should be good evaluators and should be able to warn students without offending them regarding this practise.

E8: Everything that the students do is to be assessed and absolute feedback must be given. Feedback is an important tool for the students.

c) Student should be offered multiple choice and interdisciplinary tasks should be prepared: Offering students multiple choices for their performance tasks and including interdisciplinary knowledge can enhance their motivation. Thus, every student will be able to make choices in the direction of their knowledge, skills and abilities and will thereby feel less restricted in their obligation. Example views on this are as follows.

E2: If students are given choices over their performance tasks in accordance with the class level, the students can choose performance tasks based on their own interests. Therefore, the students can be better provided with the opportunity to do performance tasks themselves.

E3: Performance tasks and the diversity of projects can be enhanced. Students can choose a task appropriate to their own resources....in interdisciplinary tasks, coordinated work by the teachers is crucial in determining the students' readiness level because it does not serve the purpose of interdisciplinary study when you do not know the time spared for the relevant topic in other courses and the student's learning.

E5: Considering the multiple intelligence approach, especially in students' performance tasks, may increase the students' motivation. Otherwise, if individuals with different abilities are expected to give outputs for one or two skills, they will not be able to realise their abilities and their motivation will reduce, or they will even seek help from outside.

\subsubsection{Evaluation}

a) Exhibition of the works: Exhibition of students' works can be seen as an important step in terms of student motivation. If the works are exhibited, the students can assume responsibility for their work. Sample views with regard to this are presented as follows.

E7: It should be stated that the purpose of these tasks is not to evaluate the students, but to encourage them to produce innovative products and ideas with the knowledge that they have acquired. For this, physical, technical and financial support should be provided to the students in order to fulfil such activities at the school level. Products produced by students can be introduced to the school environment and local community in order for these activities to reach the masses.

E8: Sharing the works done of both successful and unsuccessful students may increase their motivation. If the tasks and projects assigned involve an element of social responsibility, it can result in increased motivation of students in search of identity.

\section{DISCUSSION}

This study puts forward a model which aims to examine performance tasks being implemented at Turkish high school education institutions through analysing problems as perceived by the teachers and suggesting a solution to those problems.

In the first part of the study, it was seen that the problems encountered in the implementation of performance tasks generally matched the problems encountered with performance tasks in primary education institutions. The problems determined in this study are also parallel to the published literature (Ak, 2013; Arı, 2010; Arslan, 2013; Aydın et al., 2015; Benli, 2010; Dilekmen \& Aydoğdu, 2015; Göçgen, 2016; Karakuş \& Karakoç Öztürk, 2016; Metin, 2013; 
Sar1, 2014). These problems were difficulties experienced in time management, students creating plagiarising products by copy-pasting from the Internet, considering performance tasks as grade-oriented, overcrowded classes, and problems encountered in the preparation and assessment of performance tasks. When the results of the study are examined, it appears that the problems encountered in the implementation of performance tasks did not differ at the primary or high school education level.

In order to be able to overcome the problems faced, academicians were consulted in the fields of Measurement and Evaluation in Education, Curriculum and Instruction, Educational Administration and Planning, and Psychological Counselling and Guidance. Three main stakeholders were involved in the model created in accordance with their opinions, which are the University, the MoNE and Teachers.

There has to be constant collaboration between these three stakeholders. University's should be aware of problems in implementations and should be able to present solutions to them; the MoNE should provide the necessary conditions to support teachers; and teachers should share the difficulties, problems and disabilities they encounter with the other stakeholders.

The university stakeholder focuses on the fully-equipped graduation of teacher candidates who have not yet fulfilled their teaching profession. For this reason, teacher candidates should be highly mastered in their undergraduate educational sciences courses. In particular, it could be understood from the interviews that the content of the Measurement and Assessment course in Education should be updated in such a way to be of more use when teachers start to practice their profession. Another suggestion was that the subjects of development, implementation, and evaluation of measurement instruments which cannot be covered in detail on the course could be given under a different course within the curriculum. If prospective teachers undertake more practical work, they will be more aware of the essential features of performance tasks while practising their teaching profession. Besides, it should also not be forgotten that it does not mean that prospective teachers will implement performance tasks more effectively if they are successful only in the Measurement and Evaluation in Education course. With the Curriculum and Instructional training course, they can use performance tasks as a learning activity. Performance assessment can be seen as part of classroom instruction (Marzano, Pickering, \& McTighe, 1993) and it is an important tool for learning and teaching (Darling-Hammond, 1994; Messick, 1994). Implementation in the classroom with a classroom management course can make it easier to implement these tasks through facilitating its implementation. Also, with the Psychological Counselling and Guidance course, performance tasks can be created by paying attention not only to the cognitive level of the students, but also to the students' developmental characteristics. For the teachers engaged in the teaching profession; seminars, workshops and in-service teacher training are recommended by the universities. Therefore, both the fulfilment of lifelong learning principle and the teachers' lack of knowledge should be considered.

For the MoNE as a stakeholder, it is suggested to create a pool of performance tasks that teachers can use. Teachers can perform the implementations more effectively if they have wellprepared performance tasks to hand and the rubrics with which to grade them. It is also necessary to provide environments where the teachers can communicate with each other and share information on a platform on which detailed examples are presented. In this respect, teachers from the same branches, but in different regions and who have different experiences can benefit from each other's experiences and learn from each other as colleagues. In addition, in-service teacher training provided by the MoNE should be determined according to the teachers' needs in order to be more effective. If necessary, training should be done within an online environment to enable active participation of each teacher. In the scope of in-service teacher training; it is suggested that teachers should be encouraged to participate in activities such as congresses, symposiums, training courses relevant to their branch and their personal 
development activities. In this way, it can be ensured that teachers actualise themselves professionally.

The teacher as stakeholder is the proposed model's focus. Based on the findings of the teachers' opinions, it can be concluded that teachers do not see themselves as adequate in the preparation, implementation and evaluation of performance tasks. In line with this result, it is necessary for the teachers to completely know the features, types, implementation diversity and scoring types of the performance tasks. In the proposed model, the topics that teachers should pay attention to are grouped under the stages of preparation, implementation and evaluation.

In the preparation phase; the purpose of performance tasks should be presented clearly to the students (Herman, Aschbacher, \& Winters, 1992; Perlman, 2003). Thus, the students will better understand why and what they are expected to do. In the literature, it is seen that in studies of teachers and students at the primary education level, the student's inability to understand the purpose of the task caused problems during the preparation of the performance task (Akdağ \& Çoklar, 2009; Arı, 2010; Hacısalihoğlu, 2013). Similarly to the findings of the current study, Aydin et al. (2015) found that the performance tasks were not suitable for all students.

The appropriateness of the task to the environment and to the student's level will encourage the students to undertake performance tasks on their own. Taking into consideration the developmental characteristics of students, especially at the high school education level which corresponds to the adolescence period, tasting the sense of accomplishing something will encourage the student to do the performance tasks. This can also help to reduce the parental attitudes of helping with assignments (Güvey, 2009; Orhan, 2007; Şeker, 2009, Tüysüz, Karakuyu, \& Tatar, 2010). Other points to be aware of during the preparation phase of the performance tasks are the rubrics and sharing the sample performance tasks with the students. Rubrics can also be used effectively for the feedback of performance tasks (Cargas, Williams, \& Rosenberg, 2017; Chappuis, Stiggins, Chappuis, \& Arter, 2014, McTighe, 2016; McTighe $\&$ Ferrara, 1998). One of the important problems faced by teachers in the implementation of the performance tasks is lack of time. It is recommended to prepare work plans so that they can solve this problem.

In the implication phase; the basis of the proposals is the diversification of the implementation of performance tasks. Some suggestions were provided to the problems encountered. These problems are that the classrooms are crowded, that the student's performance tasks are only seen an opportunity for grading, that it takes too much time to assess the tasks as teachers have too many performance tasks to supervise, and that the Internet can be used as a source. When the experts' opinions are considered in general; the importance is seen of teacher consultation in the implementation of performance tasks. When overcrowded classes and the characteristics of the students' developmental period are considered, it can be suggested that performance tasks should be organised within the context of a collaborative approach. If the purpose is to increase student motivation, the performance tasks that give students the opportunity to choose the performance task can be prepared. Instead of assigning individual performance tasks for each course, the workload can be reduced by preparing interdisciplinary performance tasks.

In the evaluation phase; it is recommended to provide rubrics from which to grade the students' tasks, provide feedback to the students, and to exhibit the students' works. In the assessment stage, the experts' opinions suggested displaying the students' performance tasks within the context of an activity, which may positively affect the students' attitudes towards the courses and their personality development. McTighe and Ferrara (1994) also stated that the presentation of performance tasks to family and friends positively influenced student motivation. School administrators and parents need to take an active part in this process in order to undertake such activities. In addition, the students must be given feedback at this stage of the performance 
tasks. The rubrics can be used to structure the feedback. Clear and explicit scoring of the works provides an opportunity for the students to see their own strengths and weaknesses.

\section{ORCID}

Melek Gülşah Şahin (D) orcid.org/0000-0001-5139-9777

Nagihan Boztunç Öztürk (iD orcid.org/0000-0002-2777-5311

\section{REFERENCES}

Ak, S. (2013). The evaluation of performance tasks given at primary education according to students', teachers', and parents 'opinions (Unpublished Master's thesis). Çağ University, Mersin.

Akdağ, H., \& Çoklar, A.N. (2009). İlköğretim 6. ve 7. sınıf öğrencilerinin sosyal bilgiler dersi proje ve performans görevlerini hazırlarken yararlandıkları kaynaklar, internetin yeri ve karşıklaştıkları güçlükler [The resources 6th and 7th grade students use while preparing projects and performance tasks for social studies course, use of the internet as a resource, and the difficulties that they experience]. Adlyaman University Journal of Social Sciences, 2 (2), 1-16.

Arı, A. (2010). Öğretmenlere göre proje ve performans görevlerinin uygulanmasında karşılaşılan sorunlar [Difficulties which teachers face in implementing projects and performance tasks]. Electronic Journal of Social Sciences, 9(34), 32-55.

Arslan, A. (2013). Türkçe öğretmenlerinin proje ve performans ödevleri ile ilgili görüşlerinin değerlendirilmesi [Assessment of views of turkish teachers concerning projects and performance assignments]. Journal of Language and Literature Education, 2(6), 11-22.

Aslan Yolcu, F. (2013). İlkögretim düzeyinde performans görevi ve proje uygulamalart sürecinde disiplinler arası yaklaşımın etkililiği üzerine bir çalışma [Effectiveness of the interdisciplinary approach on process of performance task and project implementation at primary level] (Unpublished Doctoral dissertation). Hacettepe University, Ankara.

Aydın, H., Yörek, N., \& Uğulu, İ. (2015). Lise öğrencilerinin performans ödevlerine karşı tutumlarının bazı değişkenler açısından incelenmesi [An investigation of some variables related students' attitudes towards performance assignments]. Mustafa Kemal University Journal of Graduate School of Social Sciences, 12(31), 211-229.

Bal, A. P. (2012). İlköğretim öğrencilerinin matematik dersi performans görevi hazırlama sürecine ilişkin görüşleri ve yaşadıkları sorunlar [Primary school students' views and challenges on performance task preparation process in mathematics course]. Pegem Journal of Education and Instruction, 2(1), 11-23.

Bayrakçı, Ö. (2010). Illköğretim sosyal bilgiler dersindeki araştırma ödevlerinin (etkinlik, performans ve proje) ögrencilerin sosyalleşmesine katkısı [The contribution of the research tasks (projects, performances and activities) in social sciences to the socialization of the students] (Unpublished Master's thesis). Sakarya University, Sakarya.

Benli, N. (2010). Illkögretim I. kademede verilen performans görevlerinin ögretmen ve veli görüşleri açısından değerlendirilmesi [The evaluation of performance tasks' given in elementary education according to teachers' and parents' views] (Unpublished Master's thesis). Mustafa Kemal University, Hatay.

Cargas, S., Williams, S., \& Rosenberg, M. (2017). An approach to teaching critical thinking across disciplines using performance tasks with a common rubric. Thinking Skills and Creativity, 26, 24-37.

Chappuis, J., Stiggins, R., Chappuis, S., \& Arter, J. (2014). Classroom assessment for student learning: Doing it right - Using it well. Second Edition. Pearson 
Çiftçi, S. (2010). İlköğretim birinci kademe 4. ve 5. sınıf öğretmenlerinin performans görevlerine ilişkin görüşleri [The opinions of the teachers in upper primary classes concerning the student performance tasks]. Elementary Education Online, 9(3), 934-951.

Darling-Hammond, L. (1994). Performance-based assessment and educational equity. Harvard Educational Review, 64(1), 5-30.

Dilekmen, M., \& Aydoğdu, F. (2015). Sınıf öğretmenlerinin performans görevlerine ilişkin algilarının değerlendirilmesi [The evaluation of primary- school teachers' perceptions about performance tasks]. Erzincan Üniversitesi Sosyal Bilimler Enstitüsü Dergisi, 8(1), 51-62.

Ekici, E. (2016). Görsel sanatlar eğitiminin ögrencilerin performans görevlerine katkalarına ilişkin ögrenci görüşleri [About the contribution of visual art education to the performance duties of students] (Unpublished Master's thesis). Gazi University, Ankara.

Furat, E. (2009). Performans görevlerinin öğrencielrin fen ve teknoloji dersine ilişkin tutumlarına ve eleştirel düsünme eğilimlerine etkisi [Influence of the performance assignments on attitudes of the students towards science and technology courses and their tendencies to critical thinking] (Unpublished Master's thesis). Ankara University, Ankara.

Gelbal, S., \& Kelecioğlu, H. (2007). Öğretmenlerin ölçme ve değerlendirme yöntemleri hakkındaki yeterlik algıları ve karşılaştıkları sorunlar [Teachers' proficiency perceptions of about the measurement and evaluation techniques and the problems they confront]. $H$. U. Journal of Education, 33, 135-145.

Göçgen, S. (2016). Ortaokul 7. sınıf ögrrencilerinin sosyal bilgiler dersinde performans görevi hazırlarken karşılaştıkları sorunların incelenmesi [Examination of the problems 7th grade secondary school students encounter when they are preparing their performance mission] (Unpublished Master's thesis). Atatürk University, Erzurum.

Gürel, N. (2012). Performans görevlerinin öğrencilerin matematik başarısına ve tutumuna etkisi [The effects of performance task on students' math achievement and attitude towards mathematics] (Unpublished Master's thesis). Mehmet Akif Ersoy University, Burdur.

Güvey, E. (2009). İlkögrretim 1-5. sinıf ögretim programlarında yer alan proje ve performans görevlerine ilişkin ögretmen ve veli görüşleri [Opinions of teachers and parents related to projects and performance tasks which take part in primary school 1-5 grade education programs] (Unpublished Master's thesis). Eskişehir Osmangazi University, Eskişehir.

Hacısalihoğlu, M. (2013). 6. sinıf öğrencilerinin proje ve performans görevleriyle ilgili görüşleri ve karşılaştıkları güçlükler [6th grade students' opinions and encountered difficulties in project and performance tasks] (Unpublished Master's thesis). Karadeniz Technical University, Trabzon.

Herman, J., Aschbacher, P., \& Winters, L. (1992). A practical guide to alternative assessment. Alexandria, VA: Association for Supervision and Curriculum Development.

Karakuş, M., \& Karakoç Öztürk, B. (2016). İlköğretim Türkçe öğretmenlerinin performans değerlendirmeye yönelik görüşlerinin incelenmesi [A study of elementary school Turkish language teachers' views on performance evaluation]. Journal of Çukurova University Institute of Social Sciences, 25(1), 283-302.

Kutlu, Ö., Doğan, C. D., \& Karakaya, İ. (2009). Öğrenci başarısının belirlenmesi performansa ve portfolyoya dayall durum belirleme. Ankara: Pegem Akademi.

Marzano, R. J., Pickering, D., \& McTighe, J. (1993). Assessing student outcomes; performance assessment using the dimensions of learning model. Alexandria, VA: Association for Supervision and Curriculum Development. 
McTighe, J. (2016). Designing authentic performance tasks and rubrics. Retrieved 16 May, 2018 from

http://schd.ws/hosted_files/stlinstl2017/23/McTighe\%20Handout\%20\%232\%20MISD \%206.6.17.pdf.

McTighe, J., \& Ferrara, S. (1994). Performance-based assessment in the classroom. Retrieved 13 October, 2017 from https://www.jaymctighe.com/wordpress/wpcontent/uploads/2011/04/Performance-Based-Assessment-in-the-Classroom.pdf.

McTighe, J., \& Ferrara, S. (1998). Assessing Learning in the Classroom: Student Assessment Series. Washington, DC: National Education Association.

Messick, S. (1994). The interplay of evidence and consequences in validation of performance assessment. Educational Researcher, 23(2), 13-23.

Metin, M. (2013). Öğretmenlerin performans görevlerini hazırlarken ve uygularken karşılaştığ1 sorunlar [Teachers' difficulties in preparation and implementation of performance task]. Educational Sciences: Theory \& Practice, 13(3), 1645-1673.

Milli Eğitim Bakanlı̆̆g. (2013). Milli eğitim bakanlı̆̆ı ortaöğretim kurumlarl yönetmeliği. Retrieved 05 December, 2017 from http://www.resmigazete.gov.tr/eskiler/2013/09/20130907-4.htm.

OECD. (2012). Better skills, better jobs, better lives: a strategic approach to skills policies. Paris: OECD Publishing.

OECD. (2017). Pedagogical knowledge and the changing nature of the teaching profession. Paris: OECD Publishing.

Orhan, A.T. (2007). Fen ĕgitiminde alternatif ölçme ve dĕgerlendirme yöntemlerinin ilköğretim ögretmen adayl, ögretmen ve ögrenci boyutu dikkate alınarak incelenmesi [Exploring the alternative assessment strategies by considering primary school pre-service teachers and students dimensions]. (Unpublished Doctoral dissertation). Gazi University, Ankara.

O'Sullivan, M. K., \& Dallas, K. B. (2010). A Collaborative approach to implementing 21st Century skills in a high school senior research class . Education Libraries, 33(1), 3-9.

Öztürk, P. (2010). Illköğretim II. kademe Türkçe dersi performans görevi başarı puanlarl ile akademik başarl ve derse yönelik tutum arasındaki ilişkinin değerlendirilmesi [The evaluation of relation between success grades of Turkish lesson performance task and academic success and attitude to lesson in primary education school level] (Unpublished Master's thesis). Karadeniz Technical University, Trabzon.

P21Skills. (2007). 21 st Century skills assessment: A partnership for $21^{\text {st }}$ century skills e-paper. $\begin{array}{llll}\text { Retrieved } & \text { October, 2017, from }\end{array}$ http://www.p21.org/storage/documents/21st_Century_Skills_Assessment_e-paper.pdf.

Palaz, T., Kılcan, B., Akbaba, B., \& Çepni, O. (2015). Sosyal bilgiler dersinde verilen performans görevlerinin muhatapları tarafından değerlendirilmesi [The evaluation of performance homeworks assigned in social studies courses by respondents]. International Journal of Turkish Education Sciences, 5, 248-264.

Pellegrino, J. W. (2017). Teaching, learning and assessing 21st century skills. In S. G. (Ed.), Pedagogical knowledge and the changing nature of the teaching profession (pp. 223251). Paris: OECD Publishing.

Perlman, C. C. (2003). Performance Assessment: Designing Appropriate Performance Tasks and Scoring Rubrics. In Wall, J.E., \& Walz. G.R. (Ed.), Measuring Up: Assessment Issues for Teachers, Counselors, and Administrators (pp. 497-506). Greensboro, NC: CAPS Press.

Sar1, F. (2014). Illköğretim birinci kademe performans görevlerinin öğretmen ve veli görüşleri açısından değerlendirilmesi [An evaluation of elementary school performance tasks from 
teachers and parents' point of views] (Unpublished Master's thesis). Ondokuz May1s University, Samsun.

Seyhan, A. (2017). Ortaöğretim öğrencilerinin performans görevlerine ilişkin görüşleri [View of the secondary school student related to performance task]. Electronic Journal of Social Sciences, 16(60), 60-75.

Sözer, E. (2015). Çok seçenekli performans görevlerinin öğrencilerin akademik başarı, özgüven ve derse karşı tutumlarına etkisi [Influence of the multiple choice performance tasks on students' academic achievement, selfconfidence and attitudes of the students towards] (Unpublished Master's thesis). Gazi University, Ankara.

Şeker, M. (2009). İlköğretim 5. sınıf öğrencilerinin performans görevindeki başarıları ile ailelerinin eğitim-öğretim çalışmalarına katılım düzeyleri arasındaki ilişkinin belirlenmesi [An investigation on the relation between the success of fifth class' students' on performance works and the rate of their family support on educational -teaching works]. (Unpublished Master's thesis). Çukurova University, Adana.

Tanrıverdi, T. (2012). Illköğretim dördüncü ve beşinci sinıf ögretmen ve ögrencilerinin sosyal bilgiler dersinde performans görevine yönelik görüşleri [Fourth and fifth grade primary school teachers' and students' views about performance tasks in social studies course]. (Unpublished Master's thesis). Çukurova University, Adana.

Tavşancıl, E., \& Aslan, E. (2001). Sözel, yazllı ve diğer materyaller için içerik analizi ve uygulama örnekleri. İstanbul: Epsilon Yayınevi.

Türk Eğitim Derneği [TED]. (2014). TEDMEM 2014 Eğitim Değerlendirme Raporu. Retrieved 10 December, 2017 from https://tedmem.org/yayin/2014-egitim-degerlendirme-raporu.

Tüysüz, C., Karakuyu, Y., \& Tatar, E. (2010). Fen ve teknoloji dersindeki performans görevlerine yönelik veli tutumlarının belirlenmesi [Opinions of students' parents about performance task in science and technology class]. Necatibey Faculty of Education Electronic Journal of Science and Mathematics Education, 4(1), 108-122

Yıldırım, A., \& Şimşek, H. (2008). Sosyal bilimlerde nitel araştırma yöntemleri. Ankara: Seçkin Yayınları.

Yıldırım, K. (2010). Nitel araştırmalarda niteliği arttırma [Raising the quality in qualitative research]. Elementary Education Online, 9(1), 79-92. 